\title{
The impact of fraud-themed course on students' attitude to fraud. Does previous studies and background matter?
}

\author{
Maria Vassiljev ${ }^{1, \mathrm{a}}$ \\ ${ }^{a}$ Tallinn University of Technology, Estonia
}

\begin{abstract}
Research Question: The main research question is "Has the fraud examination had any impact on accounting and audit students' attitudes to fraud?" Motivation: The problem of financial statement fraud is still actual. Accountants and auditors need a special education about fraud and ethical values to recognize a situation of fraud. To examine the influence of a correspondent course Nguyen et al. (2008) have examined students' ethical values before and after the course of business ethics, Rennie and Rudland (2003) have researched potential impact of course on students' attitude to academic misconduct. The novelty of the study is a questionnaire built on the basis of Fraud Triangle to find out students' attitude to factors of fraud. Idea: The main idea is to examine whether the course of fraud examination changes accounting and audit students' attitude to fraud? Also, the study tries to find out is there any difference in attitude to fraud conditioned by students' background? Data: 55 postgraduate students of TalTech School of Business and Governance and 70 participants in the professional training programme "Accountant-financial officer" have filled in questionnaires in academic years 2015/2016-2018/2019. Tools: A questionnaire is chosen as a research method. Student's t-test and one-way analysis of variance (one-way ANOVA) are used to answer all research questions. Findings: The course of fraud examination has a slight positive influence on students' perception of fraud. A surprising result was that students without degree in accounting were slightly more optimistic in their ethical attitude to fraud. Younger
\end{abstract}

1 Corresponding author: Maria Vassiljev, Tallinn University of Technology, School of Business and Governance, Department of Business Administration, ORCID: 0000-00018355-759X, Researcher ID: AAG-9954-2019, maria.vassiljev@ outlook.com 
and less experienced students more than others consider it possible for fraud to be committed. Therefore the course on ethics and fraud should be integral part of continuous education of accounting professionals. Contribution: Researches on topic of how to measure a change of attitude or ethical values have been combined, Fraud Triangle is offered as a basis for questionnaire.

Keywords: attitude to fraud, auditors and accountants, professional ethics, continuous education

JEL code: A23, M41, M42, G41

\section{Introduction}

It is like a common truth that fraud is destroying for individuals, public sector, businesses and countries. A moral and a material damage is hardly measurable. Despite the fact that there are different types of fraud, different perpetrators, different damages - a common denominator is the fact that fraud is like a disease that spreads, causes harm and leaves scars. Financial statement fraud is not an exclusion. By specifying the type of fraud we can narrow the circle of participants. In this case the fraud may be committed by different perpetrators, but permanent participants are accountants and auditors. Accounting professionals, both accountants and auditors, have very essential public obligation concerning financial reporting process. Accountants are required to ensure that financial statements give a complete and realistic picture of a company's performance and financial position. By controlling financial statements, auditors should ensure a high degree of confidence in public towards management and company's vitality and success. Some authors call accountants "designers of order", like "accounting theory follows the basic assumptions of the functionalist perspective in that they contribute to accurate communication, control and the maintenance of order" (Reynolds, 2000: 116). As accountants are "designers of order", auditors could be called "supervisors of order". Their work requires making of choices and decisions, what should be objective and correct. To help accountants and auditors reduce the level of subjectivity and focus on job details, code of professional ethics was created.

Nevertheless, the code of ethics alone cannot prescribe in detail how to behave in a variety of unclear situations, as such situations are infinite. Accounting professionals should implement their ability to adopt the right decision. The author has already raised the issue of auditors' decision-making in the paper "Behavioural aspects of auditing and the auditor's decision-making as a key cognitive process in the case of fraud" (Vassiljev \& Alver, 2019). 
To answer the question what is wrong, what is right in some contentious situation help ethics and morality. "The intensity of morality plays a significant role in making ethical judgment as far as the reporting of financial data is concerned" (Alrabba, 2016: 57). With reference to Mintz, Samsonova-Taddei and Siddiqui have confirmed that "there is an intimate link between morality and the practice of making judgements. By making daily choices about what is wrong or right, auditors gain opportunities for developing practical wisdom and 'internalize' ethical virtues that, in turn, enable them to make sound ethical decisions" (Samsonova-Taddei \& Siddiqui, 2016: 193). How is it possible to help professional accountants to shape the right attitude and make the right decision? As many other authors, SamsonovaTaddei and Siddiqui propose to incorporate educational mechanisms to facilitate the development of auditors' ethical reasoning.

The topic of professional education of accounting professionals is one of the most important topics in the field. There are various debates on the content of accounting education, but there are also criticisms of the failure of the standard accounting course "to acknowledge and challenge the ethical and moral assumptions of the worldview and provide an alternative discourse in accounting education" (Irsyadillah \& Lasyoud, 2018: 463). Many researchers agree that basic knowledge of ethics, "received by the accountant and auditor during the academic stages is reflected in the quality of the financial statements prepared by companies" (Al frijat \& Albawwat, 2019: 380). With reference to international associations and standards, the International Accounting Education Standards Board (IAESB), an independent organization within the fold of the International Federation of Accountants (IFAC) should be mentioned. The IAESB has developed 'International Education Standard 4: Initial Professional Development - Professional Values, Ethics, and Attitudes' (IES 4). According to IES 4, "Professional values, ethics, and attitudes are the characteristics that identify professional accountants as members of a profession" (IAESB, 2019: 4). This confirms that to be a professional accountant means to have certain values, ethics and attitudes. Using deductive method, it is justified to suppose that professional accountant's values, ethics and attitude to fraud shape his/her behaviour on detecting fraud, also define a commitment to detect a fraud. Detecting fraud is undoubtedly difficult, however not impossible (Drogalas et al., 2017: 438). IES expect that professional accountants should be involved in a lifelong learning process, where professional values, ethics and attitudes, achieved before during initial personal development should be reviewed and updated during continuous personal development as it helps to respond to a changing environment and to foresee new ethical threats (Drogalas et al., 2017: 438).

Coming back to the topic of fraud, it is obvious to perceive that attitude to fraud, based on ethics and understanding of what is fraud, leads to professional behaviour of accounting professionals. In order to diminish a possibility of fraud it is important 
for accounting professionals to continue and constantly update their education concerning fraud and professional ethics.

According to that the aim of the paper is to examine whether the course of fraud examination changes postgraduate accounting and audit students' attitude to fraud to more ethical? Also, to find out is there any difference in attitude to fraud of postgraduate accounting and audit students and other students, is it conditioned by students' background? Corresponding research questions are asked:

RQ1 - Is postgraduate accounting and audit students' attitude to fraud before the course of fraud examination less ethical than after the course?

RQ2 - Does postgraduate accounting and audit students' attitude to fraud differ from professional courses participants' attitude to fraud?

RQ3 - Do students' backgrounds influence their attitude to fraud?

The study is limited to Estonia and Tallinn University of Technology (TalTech), one of the largest Estonian universities. At TalTech's School of Business and Governance students have the opportunity to specialize in accounting and auditing. Postgraduate students and participants of professional training programme took part in the research. The course, which presumably impact on students' attitude to fraud is the course "Fraud Examination and Forensic Accounting". The questionnaire was chosen as the research method. The novelty, proposed by the author, is that the questions in the questionnaire are built on the basis of Fraud Triangle, which allows the researcher to evaluate respondents' attitude to fraud factors as "perceived opportunity", "perceived pressure" and "rationalization". In 2016 the author has researched the topic of different fraud models, where Fraud Triangle is the most known and usable one (Vassiljev \& Alver, 2016). The methods used are Student's ttest and one-way analysis of variance (one-way ANOVA) that allow to analyze differences between "populations" to answer all research questions.

\section{Theoretical background}

Professionals' attitude to fraud, abuse or misconduct has long been of interest to many researchers. As above-mentioned unprofessional behaviour exists from ancient times, the problem is also well-known and still actual. Why does attitude to any misconduct draw researchers' attention in this way? Because attitude plays a huge role in forming humans behaviour. "Attitudes are the results of factors such as personal experience, education, information and personality type ... When people accept some stimuli, they process it and convert it into attitude that affects our feeling and recognition and then is displayed as behaviour" (Omran, 2014: 145). A significant meaning of attitude is the ability to change. For example, to change toward an attitude, what is needed to produce ethical and professional behaviour in case of fraud? 
There are several interesting researches on the topic of professionals' attitude to fraud or misconduct. For example, Rennie and Rudland in 2003 have researched attitudinal and self-reported behavioural variations between medical students in different years to scenarios involving academic misconduct. In the authors' opinion "if a relationship exists between unethical behaviour at work and at undergraduate level, the attitudes and behaviours of undergraduates need to be explored" (Rennie \& Rudland, 2003: 97). The aim of the research was to find out a potential impact of course delivery and assessment on the levels of academic misconduct. The authors have found that there is a difference to academic misconduct in attitudes of students of different years of studying. They came to the conclusion that "the importance of developing strategies to engender appropriate attitudes and behaviours at the undergraduate level must be recognised" (Rennie \& Rudland, 2003: 97). In 2009 Bierstaker has carried out a research with a purpose to examine differences in managers' and employees' attitudes about fraud across different cultures. With reference to Watson (2003) he came to the conclusion that "corporate culture may be equally or more important than one's cultural heritage when it comes to guiding ethical behaviour and shaping attitudes about fraud" (Bierstaker, 2009: 247). 15 years before Tennyson also has bound ethical theme with attitude to fraud. In 1994 he has exercised the consumers' attitudes toward the acceptability of insurance fraud. He has reached to very interesting results: "(1) an individual's attitudes will be influenced by the ethical or social environment for fraud, and (2) tolerant attitudes toward fraud will be expressed more often by individuals who have negative perceptions of insurance institutions ... these findings confirm the importance of the ethical climate in determining attitudes toward insurance fraud" (Tennyson, 1997: 260). In 2003 Singleton et al. have also researched the topic of pro-ethic activities and fraud. They have analysed the data from the U.S. Sentencing Commission and came to the conclusion that "there appears to be a correlation between ethics and fraud. For example, certain ethical attitudes, such as dishonesty and overaggressive behaviour, seem to be antecedents to fraud" (Singleton et al., 2003: 87). There is no doubt that ethics influences people and their attitudes. Professional ethics for accounting professionals is not an exclusion.

In the easiest way ethics can be defined as study of what is morally right and what is wrong. Ethics (Greek Ethos = custom, usage, miracle) is defined as a set of habits, the rule of a person, a nation or a class (Todorovic, 2018: 136). Ethics can also be defined as "an inquiry into the nature and background of morality" (Rozidi et al., 2015: 82). In 1950 Abraham Maslow has developed hierarchy of human needs, also known as Maslow's Pyramid of Needs (Stum, 2001). Ethics belong to human social needs, the third tier in Maslow's hierarchy of needs (Bruce, 2012), what makes human to behave like a social human, interacting with others. Ethics is one of the bricks that form the basis of the civilized world. Professional ethics is one of the bases, which ensures order and professionalism in the job. 
The topic of professional ethics is not a new nor specific one. There are many studies that emphasize the importance of ethics and try to evaluate its impact on professional performance. In 1992 Callan explored employees' ethical values and training needs. He supposed that socio-demographic need may be one of the factors that influence the ethical values of employees. After research, he came to the conclusion that employee status is important, also employees' level of external contact influences ethical values. "The gender, age and length of service of the respondent did not substantially influence ethical values" (Callan, 1992: 769).

A few years later the researchers Cole and Smith have assessed perceptions of business ethics of business students and business practitioners. 537 questionnaires were fulfilled by students of several business schools in the USA, 158 questionnaires were received from white-colour business people. The results of their study are intriguing in some way. The most astonishing result was that "students have weaker ethical values than experienced business people", also that "they have an unrealistically negative view of the ethics of business people" (Cole \& Smith, 1996: 892). There was no difference in perception of business people by gender, but the results of female students were more ethical results. According to the main finding, the authors supposed, that "they were still holding some of their preconceived negative opinions of "typical" business behaviour. As they gain experience with the company and become more attuned to the company culture, their opinions of typical business ethics may become more positive" (Cole \& Smith, 1996: 895).

Accounting professionals, especially auditors, have always been in the focus of public attention due to a great responsibility of their work and an increasing number of audit failures, connected with an unprofessional behaviour of some of representatives of the profession. As several authors argue, "current crisis of confidence is certainly a consequence of the lack of ethics in the behaviour of almost all participants in the financial reporting chain" (Todorovic, 2018: 138). Researchers in the field are trying to find out the reasons behind this unprofessionalism in order to help eliminate them. For example, Barrainkua and Espinosa-Pike have researched in 2017 auditors' commitment to professionalism. The study analysed "whether the professional values of postgraduate students' differ from those of experienced auditors, and among auditors at different career stages" (Barrainkua \& EspinosaPike, 2017: 176). After the analysis of surveys of both target groups the authors have got interesting results: they found that "students' commitment to the public interest and independence enforcement is significantly higher than auditors' values" (Barrainkua \& Espinosa-Pike, 2017: 177). In addition, they found out that both values decrease as auditors get more experienced. Nevertheless, the auditors have shown higher ethical judgement than students. The authors supposed that "auditors may have experienced similar ethical dilemmas in the course of their job, and may therefore be more aware of which should be the acceptable behaviour" (Barrainkua \& Espinosa-Pike, 2017: 184). One of the most important suggestions made by the authors is that ethical training should not stop within a higher education, the training 
with focus on professional ethical values and responsibility should be the part of “continuous professional development" (Barrainkua \& Espinosa-Pike, 2017: 184).

Auditors are supposed to be very qualified, genuine professionals and experts, who implicitly follow audit standards and observe an execution of accounting principles. But "when they do not employ the ethics of their profession, they will not be able to provide any benefits to the audit profession as a whole" (Rozidi et al., 2015: 82). The professions of accountant and auditor are of that kind of workplaces, where ethical dilemmas are common occurrences as there they often have to make a decision on question, where the answer in not always black or white. According to that "study of accounting ethics is required as it is an essential aspect of the roles of auditors and accountants in preparation of financial statements" (Jaijairam, 2017: 2). Taking into consideration the meaning of professional accountants' contribution to society, it is obvious statement that they should strictly adhere the principles of accounting's professional ethics.

The author agrees with Jaijairam (2017), who defines the problem of professional ethics of accountants and auditors as ethics influenced by both organizational codes of ethics and individual personal values. The problem exists in identification of which factor influences ethical behaviour more: organizational culture through a code of ethics or the accountants' /auditors' individual outlook on ethics. If the first variable depends on a particular organization and other environment, the second one can be improved and perfected by continuous studying of professional ethics. "The ultimate goal of an ethics education is to produce more ethical behaviour, a precursor of which is ethical intention" (Nguyen et al., 2008: 73).

In 2008, Nguyen et al. have examined students' learning of business ethics. The authors asked 262 undergraduate students to provide ethical judgment rating, first at the beginning of the semester and again at the end of the semester. The purpose of the study was "to enhance students' learning of ethical judgment, which is a small but important part of an individual's ethical reasoning skill" (Nguyen et al., 2008: 73). The results of the study confirmed that the amount of learning "significantly predicts unethical behavioural intent: the more that students learned, the less likely they were to report that they would engage in the behaviours depicted in the scenarios" (Nguyen et al., 2008: 74).

As professional ethics and problems of misbehaviour exist in other areas of activity, it is appropriate to bring an example of Vuckovic-Dekic et al. (2012), who have studied the impact of short ethics courses on the knowledge of basic principles of responsible conduct of research and on the attitude toward scientific fraud among young biomedical researchers. 361 attendees of the course on ethics answered a questionnaire before and after a one-day course in ethics. The results of the research have confirmed that "even a short course of lectures in research integrity changed 
considerably the perceptions and attitudes toward violations of rules of good scientific practices" (Vuckovic-Dekic et al., 2012: 394). Using the practices of above-mentioned studies and by adding specific bases to the principles of a questionnaire, the author has carried out a following research.

\section{Methodology}

With a purpose to specify existing and future accounting specialists' attitude to fraud a questionnaire is chosen as a research method. The questionnaire is of 3 types, depending a target group. All the questionnaires are a combination of open-ended questions and questions with Likert scale. The research was carried out at Tallinn University of Technology (TalTech) in academic years 2015/2016, 2016/2017, 2017/2018, 2018/2019.

\subsection{Questionnaire}

In order to get to know what attitude to fraud have students, who have already got a degree in business and continue their studies, postgraduate students of TalTech's School of Business and Governance were chosen as a target group. The course "Fraud Examination and Forensic Accounting" was the only course, where students could get knowledge on fraud in general and in detail, why fraud occurs and how to investigate a fraud case. Proceeding with the purpose to get to know whether the course has any effect on students' attitudes to fraud, the author has interviewed students before and after the course. The same research method was used by Nquyen in 2008, where he has asked undergraduate students to provide ethical judgment rating, first at the beginning of the semester and again at the end of the semester. There were two types of questionnaires for students: the pre-course questionnaire and the post-course questionnaire. The first questionnaire included background questions (gender, age, education, work position, work experience, type and size of business), questions about students' expectations of the course, two open-ended questions on topic of fraud and twelve 7-point Likert scale questions on topic of attitude to fraud (Appendix A). The second questionnaire also included the same background questions and the same Likert scale questions. Open-ended questions consisted of course feedback (Appendix B).

In order to answer the second research question (RQ2), the author targeted participants of the professional training programme on accounting at TalTech. The third type of the questionnaire was combined for the third target group. The questionnaire also included the same background questions and the same Likert scale questions. Open-ended questions consisted of two questions on a topic of attitude to fraud (Appendix C). 
The background questions and Likert scale questions 1-8 (questions 7-14 in the questionnaire) were used in the research. These Likert scale questions were designed in such a way that questions $(1,3,8)$ help shape attitudes to the "perceived pressure" factor of Fraud Triangle. Questions (2, 4, 5) were connected with the "rationalization" factor of Fraud Triangle and questions $(6,7)$ were aimed to define an attitude to "perceived opportunity" factor of Fraud Triangle (Table 1).

Table 1. Questionnaire's Likert scale questions and points, connection with the Fraud Triangle factors

\begin{tabular}{|c|c|c|c|c|c|c|c|c|}
\hline $\begin{array}{l}\text { Likert } \\
\text { scale }\end{array}$ & $\begin{array}{c}\text { Entirely } \\
\text { disagree } \\
\text { (1) }\end{array}$ & $\begin{array}{c}\text { Mostly } \\
\text { disagree } \\
\text { (2) }\end{array}$ & $\begin{array}{c}\text { Some- } \\
\text { what } \\
\text { disagree } \\
(3)\end{array}$ & $\begin{array}{c}\text { Neither } \\
\text { agree nor } \\
\text { disagree } \\
\text { (4) }\end{array}$ & $\begin{array}{c}\text { Somewhat } \\
\text { agree } \\
\text { (5) }\end{array}$ & $\begin{array}{l}\text { Mostly } \\
\text { agree } \\
\text { (6) }\end{array}$ & $\begin{array}{c}\text { Entirely } \\
\text { agree } \\
\text { (7) }\end{array}$ & $\begin{array}{c}\text { Fraud } \\
\text { Triangle' } \\
\text { factors }\end{array}$ \\
\hline
\end{tabular}

1. Sometimes the business also has to do some so-called "suspicious

perceived transactions" because competition forces it to do so.

pressure

2. If an insignificant change in the accounting records and/or financial statements is in the interest of the company, this is permitted.

rationalization

3. The stringent requirements imposed by financial institutions and implementing agencies providing EU grants, force to change the financial reporting to comply.

perceived

pressure

4. Temporary distortion a business's financial performance to obtain an investment or grant is not a fraud.

rationalization

5. When it comes to business "survival", adjustments in accounting and/or financial reporting are justified.

rationalization

6. As most micro-entities are not subjects to audit and review, more fraud may perceived be found in their books and financial statements.

opportunity

7. Due to inefficiencies in the audit, the accounting records and financial statements may be distorted if necessary.

perceived opportunity

8. If the head of the business instructs the accountant to amend the accounting perceived records and / or financial statements, the accountant will be forced to do so. pressure

(Source: compiled by the author on basis of questionnaire (Appendices $A-C)$ )

\subsection{Samples and data gathering}

According to the aim of the research TalTech's postgraduate students were chosen as a target group. They have already obtained a degree in business and should have a general attitude to fraud, at least on the basis of previous courses of business ethics and accounting. The course "Fraud Examination and Forensic Accounting"i was assigned for accounting and auditing students as an optional subject. As a result, the 
first sample group included students who had chosen the subject. At first time the questionnaire was given to students at the first lecture and the second time at the exam. The research was performed from the academic year 2015/2016 to the academic year 2018/2019.

In order to answer the second research question (RQ2) the second sample was selected from among people who wanted to gain accounting knowledge and had come from outside TalTech to participate in the professional training programme "Accountant-financial officer". There were no education or specialization requirements to apply for the programme. The students were asked to complete the questionnaire only once, during the first or second lecture of the course "Basics of accounting". The research was performed three times. The sample sizes of both target groups are given in Table 2 .

Table 2. Sample sizes and target groups

\begin{tabular}{ccccc}
\hline Year & $\begin{array}{c}\text { Students at } \\
\text { course } \\
\text { (declared) }\end{array}$ & $\begin{array}{c}\text { Questionnaires } \\
\text { before course }\end{array}$ & $\begin{array}{c}\text { Questionnaires } \\
\text { after course }\end{array}$ & $\begin{array}{c}\text { Questionnaires } \\
\text { for participants } \\
\text { in the } \\
\text { professional } \\
\text { training } \\
\text { programme }\end{array}$ \\
\hline $2015 / 2016$ & 20 & 16 & 13 & 26 \\
$2016 / 2017$ & 25 & 16 & 19 & 17 \\
$2017 / 2018$ & 16 & 14 & 11 & 27 \\
$2018 / 2019$ & 16 & 9 & 12 & - \\
Total & $\mathbf{7 7}$ & $\mathbf{5 5}$ & $\mathbf{5 5}$ & $\mathbf{7 0}$ \\
\hline
\end{tabular}

\subsection{Analysis}

Student's t-test and one-way analysis of variance (one-way ANOVA) are used to answer all research questions. To answer RQ1, the author compared the responses of students enrolled in the course "Fraud Examination and Forensic Accounting" before ("students before the course", the first target group) and after completing the course ("students after the course", the second target group). For every question with Likert scale a $t$-test was applied to average meanings of the groups' answers to the question in order to examine whether students' responses to the questions have changed since completing the course.

In order to answer RQ2 the author has compared the answers of students, who have chosen the course, before taking the course (the first target group) with answers of people, who applied for professional training programme (the third target group). For every question with Likert scale a t-test was applied to average meanings of the groups' answers to the question to examine whether students' answers to the questions are different in their indulgence to fraud. 
To answer RQ3, the author has grouped the questionnaires of students, started studying the course "Fraud Examination and Forensic Accounting" (before the course, the first target group), with questionnaires of people, studied at the professional training programme (the third target group). All the questionnaires were grouped by 5 background factors: age, education, work experience, work position, type and size of business. The comparison of groups by gender was not exercised because the representation of male-students was under $6 \%$.

For further testing of the mean values of the groups divided according to abovementioned factors, four of the eight questions were selected: Question 1, Question 4, Question 6 and Question 8 (Table 1). Student's t-test (comparing means of two groups) and one-way ANOVA (comparing means of three groups) were applied to examine a hypothetical difference in attitude to fraud caused by students' background factors.

Testing was performed in Microsoft Excel. According to target groups the following Data Analysis tools were used:

1. 't-test paired two samples for means' comparing the answers of 'students before the course' and 'students after the course' (paired two-sample Student's t-test to ascertain if means of two populations are equal). If t Stat is greater than the $t$ Critical, the mean of one "population" is higher than the mean of the other "population";

2. 't-test two-sample assuming unequal variances' when comparing the answers of 'students before the course' and 'participants in the professional training programme' (tool to determine whether there is any indication of a difference between the means of the two different populations). If t Stat is greater than the t Critical, the mean of one "population" is higher than the mean of the other "population";

3. 'ANOVA Single Factor' was used to test students' answers, grouped by different background issues (a tool for testing different groups, more than 2 to see if there are significant differences between them). If the p-value from the ANOVA test is less than or equal to the alpha (in the case 0.05), then there is a significant difference between the groups.

\section{Results}

After the calculations the test results were combined to Tables 3-9 according to the research question and group. Table 3 shows the results of testing of students' answers to questions before and after taking the course "Fraud Examination and Forensic Accounting" to examine whether the course affects students' attitudes to fraud. 
Table 3. The results of testing the answers of students before and after taking the course

\begin{tabular}{|c|c|c|c|c|c|}
\hline Questions & Groups & Count & Average & t Stat & $\begin{array}{l}\text { t Critical } \\
\text { one-tail }\end{array}$ \\
\hline \multirow{2}{*}{$\begin{array}{l}\text { 1. Sometimes the business also has to } \\
\text { do some so-called "suspicious } \\
\text { transactions" because competition }\end{array}$} & Group $I^{i i}$ & 53 & 3.038 & \multirow[t]{2}{*}{2.948} & \multirow[t]{2}{*}{1.675} \\
\hline & Group $2^{i i i}$ & 53 & 2.151 & & \\
\hline \multirow{2}{*}{$\begin{array}{l}\text { 2. If an insignificant change in the } \\
\text { accounting records and / or financial } \\
\text { statements is in the interest of the }\end{array}$} & Group 1 & 54 & 2.833 & \multirow[t]{2}{*}{1.898} & \multirow[t]{2}{*}{1.674} \\
\hline & Group 2 & 54 & 2.259 & & \\
\hline \multirow{2}{*}{$\begin{array}{l}\text { 3. The stringent requirements imposed } \\
\text { by financial institutions and } \\
\text { implementing agencies providing EU } \\
\text { grants, force to change the financial }\end{array}$} & Group 1 & 54 & 4.296 & \multirow[t]{2}{*}{1.177} & \multirow[t]{2}{*}{1.674} \\
\hline & Group 2 & 54 & 3.889 & & \\
\hline \multirow{4}{*}{$\begin{array}{l}\text { 4. Temporary distortion a business's } \\
\text { financial performance to obtain an } \\
\text { investment or grant is not a fraud. } \\
\text { 5. When it comes to business } \\
\text { "survival", adjustments in accounting } \\
\text { and / or financial reporting are }\end{array}$} & Group 1 & 54 & 1.981 & \multirow[t]{2}{*}{1.096} & \multirow[t]{2}{*}{1.674} \\
\hline & Group 2 & 54 & 1.740 & & \\
\hline & Group 1 & 53 & 2.283 & \multirow[t]{2}{*}{1.274} & \multirow[t]{2}{*}{1.675} \\
\hline & Group 2 & 53 & 1.906 & & \\
\hline \multirow{2}{*}{$\begin{array}{l}\text { 6. As most micro-entities are not } \\
\text { subjects to audit and review, more } \\
\text { fraud may be found in their books and }\end{array}$} & Group 2 & 54 & 5.185 & \multirow[t]{2}{*}{0.506} & \multirow[t]{2}{*}{1.674} \\
\hline & Group 1 & 54 & 5.056 & & \\
\hline $\begin{array}{l}\text { 7. Due to inefficiencies in the audit, the } \\
\text { accounting records and financial }\end{array}$ & Group 1 & 54 & 4.444 & \multirow[t]{2}{*}{0.069} & \multirow[t]{2}{*}{1.674} \\
\hline $\begin{array}{l}\text { statements may be distorted if } \\
\text { necessary. }\end{array}$ & Group 2 & 54 & 4.426 & & \\
\hline $\begin{array}{l}\text { 8. If the head of the business instructs } \\
\text { the accountant to amend the }\end{array}$ & Group 1 & 54 & 3.056 & \multirow[t]{2}{*}{1.188} & \multirow[t]{2}{*}{1.674} \\
\hline $\begin{array}{l}\text { accounting records and / or financial } \\
\text { statements, the accountant will be }\end{array}$ & Group 2 & 54 & 2.667 & & \\
\hline
\end{tabular}

According to Table 3, there are two questions, where the means of answers of group of students before taking the course (Group 1) are higher than means of answers of students after completing the course (Group 2). This means that students before taking the course are more indulgent concerning a possible fraud, justified by the pressure factor of Fraud Triangle than students after completing the course (Question 1) and students before taking the course are more indulgent concerning a possible fraud, justified by the rationalization factor of Fraud Triangle than students after completing the course (Question 2). There are other questions about attitude to fraud, justified by pressure factor (Question 3, Question 8) and justified by rationalization factor (Question 4, Question 5). Nevertheless, only students' answers to Question 1 and Question 2 were different after completing the course. The main difference between Question 1 and Question 2 and the other questions is that they are intended to describe the most widespread situation and the most unethical understanding of 
possible behaviour in that situation. After completing the course, students have shown a more ethical and less indulgent attitude toward possible fraudulent situations.

Table 4 shows the results of the calculations, performed on responses to the questionnaires, fulfilled by the students before taking the "Fraud Examination and Forensic Accounting" course and by the participants in the professional training programme in order to answer RQ2.

Table 4. The results of testing students before taking the course and participants in the professional training programme

\begin{tabular}{|c|c|c|c|c|c|}
\hline Questions & Groups & Count & Average & t Stat & $\begin{array}{c}\text { t Critical } \\
\text { one-tail }\end{array}$ \\
\hline \multirow{4}{*}{$\begin{array}{l}\text { 1. Sometimes the business also has to } \\
\text { do some so-called "suspicious } \\
\text { transactions" because competition } \\
\text { forces it to do so. } \\
2 \text {. If an insignificant change in the } \\
\text { accounting records and / or financial } \\
\text { statements is in the interest of the }\end{array}$} & Group 1 & 53 & 3.038 & \multirow[t]{2}{*}{0.937} & \multirow[t]{2}{*}{1.658} \\
\hline & Group $3^{i v}$ & 70 & 2.786 & & \\
\hline & Group 3 & 69 & 3.116 & \multirow[t]{2}{*}{1.050} & \multirow[t]{2}{*}{1.658} \\
\hline & Group 1 & 54 & 2.833 & & \\
\hline \multirow{2}{*}{$\begin{array}{l}\text { 3. The stringent requirements imposed } \\
\text { by financial institutions and } \\
\text { implementing agencies providing EU } \\
\text { grants, force to change the financial }\end{array}$} & Group 3 & 67 & 4.657 & \multirow[t]{2}{*}{1.137} & \multirow[t]{2}{*}{1.658} \\
\hline & Group 1 & 54 & 4.296 & & \\
\hline \multirow{2}{*}{$\begin{array}{l}\text { 4. Temporary distortion a business's } \\
\text { financial performance to obtain an } \\
\text { investment or grant is not a fraud. }\end{array}$} & Group 3 & 70 & 2.000 & \multirow[t]{2}{*}{0.092} & \multirow[t]{2}{*}{1.657} \\
\hline & Group 1 & 54 & 1.981 & & \\
\hline \multirow{2}{*}{$\begin{array}{l}\text { 5. When it comes to business } \\
\text { "survival", adjustments in accounting } \\
\text { and / or financial reporting are justified. }\end{array}$} & Group 3 & 70 & 2.600 & \multirow[t]{2}{*}{1.335} & \multirow[t]{2}{*}{1.658} \\
\hline & Group 1 & 53 & 2.283 & & \\
\hline \multirow{2}{*}{$\begin{array}{l}\text { 6. As most micro-entities are not } \\
\text { subjects to audit and review, more } \\
\text { fraud may be found in their books and }\end{array}$} & Group 1 & 54 & 5.056 & \multirow[t]{2}{*}{3.429} & \multirow[t]{2}{*}{1.658} \\
\hline & Group 3 & 68 & 4.132 & & \\
\hline \multirow{2}{*}{$\begin{array}{l}\text { 7. Due to inefficiencies in the audit, the } \\
\text { accounting records and financial } \\
\text { statements may be distorted if }\end{array}$} & Group 1 & 54 & 4.444 & \multirow[t]{2}{*}{3.357} & \multirow[t]{2}{*}{1.658} \\
\hline & Group 3 & 69 & 3.464 & & \\
\hline \multirow{2}{*}{$\begin{array}{l}\text { 8. If the head of the business instructs } \\
\text { the accountant to amend the accounting } \\
\text { records and / or financial statements, } \\
\text { the accountant will be forced to do so. }\end{array}$} & Group 1 & 54 & 3.056 & \multirow[t]{2}{*}{2.023} & \multirow[t]{2}{*}{1.659} \\
\hline & Group 3 & 70 & 2.429 & & \\
\hline
\end{tabular}

Testing the questionnaire responses of the first target group (Group 1) and the third target group (Group 3) shows that there are three questions, where students before taking the course have shown their less firm attitude to possible frauds. The answers to Questions 6 and 7 showed that justified by the perceived opportunity factor of 
Fraud Triangle before taking the course students are more indulgent concerning a possible fraud, than participants in the professional training programme and the answer to Question 8 has confirmed that justified by the pressure factor of Fraud Triangle, before taking the course students are more indulgent concerning a possible fraud than participants in the professional training programme. Question 6 and Question 7 were the only questions, testing the attitude to possible fraud, committed in a situation where there is no control. Question 8 differs from Questions 1 and 3 by the object of pressure - in Question 1 and Question 3 the object is business, its potential to compete. The object of pressure in Question 8 is the accountant, the person whose working position depends on the head of the business. Table 5 shows the results of testing the answers of Group 1 and Group 3 students, broken down by age factors into 3 groups, to examine the hypothetical difference in students' attitudes toward fraud.

Table 5. The results of testing students before taking the course and participants in the professional training programme (broken down by age)

\begin{tabular}{|c|c|c|c|c|c|c|}
\hline Questions & Groups & Count & Average & P-value & $\mathbf{F}$ & F crit \\
\hline \multirow{3}{*}{$\begin{array}{l}\text { 1. Sometimes the business also has } \\
\text { to do some so-called "suspicious } \\
\text { transactions" because competition } \\
\text { forces it to do so. }\end{array}$} & $20-29$ & 48 & 3.104 & \multirow[t]{3}{*}{0.444} & \multirow[t]{3}{*}{0.817} & \multirow[t]{3}{*}{3.072} \\
\hline & $30-39$ & 45 & 2.800 & & & \\
\hline & $\geq 40$ & 30 & 2.700 & & & \\
\hline \multirow{3}{*}{$\begin{array}{l}\text { 4. Temporary distortion a business's } \\
\text { financial performance to obtain an } \\
\text { investment or grant is not a fraud. }\end{array}$} & $20-29$ & 48 & 2.021 & \multirow[t]{3}{*}{0.911} & \multirow[t]{3}{*}{0.093} & \multirow[t]{3}{*}{3.071} \\
\hline & $30-39$ & 45 & 1.933 & & & \\
\hline & $\geq 40$ & 31 & 2.032 & & & \\
\hline \multirow{3}{*}{$\begin{array}{l}\text { 6. As most micro-entities are not } \\
\text { subjects to audit and review, more } \\
\text { fraud may be found in their books } \\
\text { and financial statements. }\end{array}$} & 20-29 & 48 & 4.938 & \multirow[t]{3}{*}{0.027} & \multirow[t]{3}{*}{3.738} & \multirow[t]{3}{*}{3.072} \\
\hline & $30-39$ & 44 & 4.500 & & & \\
\hline & $\geq 40$ & 30 & 3.967 & & & \\
\hline \multirow{3}{*}{$\begin{array}{l}\text { 8. If the head of the business } \\
\text { instructs the accountant to amend the } \\
\text { accounting records and / or financial } \\
\text { statements, the accountant will be } \\
\text { forced to do so. }\end{array}$} & 20-29 & 48 & 3.125 & \multirow[t]{3}{*}{0.031} & \multirow[t]{3}{*}{3.559} & \multirow[t]{3}{*}{3.071} \\
\hline & 30-39 & 45 & 2.667 & & & \\
\hline & $\geq 40$ & 31 & 2.097 & & & \\
\hline
\end{tabular}

The results show that in case of Question 6 and Question 8 the answers of students, broken down by age, differ: there is a difference in attitude towards possible fraud, which is justified by the perceived opportunity factor of the Fraud Triangle (Question 6 ) and there is a difference in attitude towards possible pressure to commit a fraud of students of different age (Question 8). Question 6 is by meaning a test of attitude of students to possible fraud, committed in a situation where there is no control. In this interpretation this means that students of different ages have different attitudes towards fraud, specifically, the younger were the students were the less attitudes they had to the possible lack of control over fraud. Question 8 refers to a situation where 
fraud becomes possible due to person, who is an accountant - object of pressure, a person whose working position depends on the head of the business.

Table 6 shows the results of the calculations, performed on responses to the questionnaires, fulfilled by students before taking the course "Fraud Examination and Forensic Accounting" and people, who participated in professional training programme, broken down into two groups according to their education, with the aim to answer the RQ3 in part.

Table 6. The results of testing students before taking the course and participants in the professional training programme (broken down by education)

\begin{tabular}{|c|c|c|c|c|c|}
\hline Questions & Groups & Count & Average & t Stat & $\begin{array}{c}\text { t Critical } \\
\text { one-tail }\end{array}$ \\
\hline $\begin{array}{l}\text { 1. Sometimes the business also } \\
\text { has to do some so-called } \\
\text { "suspicious transactions" }\end{array}$ & $\begin{array}{l}\text { business } \\
\text { education }\end{array}$ & 86 & 2.953 & \multirow[t]{2}{*}{0.693} & \multirow[t]{2}{*}{1.666} \\
\hline $\begin{array}{l}\text { because competition forces it to } \\
\text { do so. }\end{array}$ & $\begin{array}{l}\text { other } \\
\text { education }\end{array}$ & 37 & 2.757 & & \\
\hline $\begin{array}{l}\text { 4. Temporary distortion a } \\
\text { business's financial } \\
\text { performance to obtain an }\end{array}$ & $\begin{array}{l}\text { business } \\
\text { education }\end{array}$ & 87 & 2.034 & \multirow[t]{2}{*}{0.677} & \multirow[t]{2}{*}{1.665} \\
\hline $\begin{array}{l}\text { investment or grant is not a } \\
\text { fraud. }\end{array}$ & $\begin{array}{l}\text { other } \\
\text { education }\end{array}$ & 37 & 1.892 & & \\
\hline $\begin{array}{l}\text { 6. As most micro-entities are } \\
\text { not subjects to audit and }\end{array}$ & $\begin{array}{l}\text { business } \\
\text { education }\end{array}$ & 84 & 4.750 & \multirow[t]{2}{*}{2.379} & \multirow[t]{2}{*}{1.670} \\
\hline $\begin{array}{l}\text { review, more fraud may be } \\
\text { found in their books and } \\
\text { financial statements. }\end{array}$ & $\begin{array}{l}\text { other } \\
\text { education }\end{array}$ & 36 & 4.000 & & \\
\hline $\begin{array}{l}\text { 8. If the head of the business } \\
\text { instructs the accountant to } \\
\text { amend the accounting records }\end{array}$ & $\begin{array}{l}\text { business } \\
\text { education }\end{array}$ & 87 & 2.805 & \multirow[t]{2}{*}{1.118} & \multirow[t]{2}{*}{1.663} \\
\hline $\begin{array}{l}\text { and / or financial statements, } \\
\text { the accountant will be forced to } \\
\text { do so. }\end{array}$ & $\begin{array}{l}\text { other } \\
\text { education }\end{array}$ & 37 & 2.459 & & \\
\hline
\end{tabular}

The results show that the only situation, where the attitude to possible fraud of students with business education is more indulgent than attitude of students with other education is a case of fraud, committed in a situation of a poor control.

Table 7 shows the results of testing the answers of Group 1 and Group 3, broken down by factor of size and type of business into 3 groups, to examine the hypothetical difference in students' attitudes to fraud. 
Table 7. The results of testing students before taking the course and participants in the professional training programme (broken down by type and size of business)

\begin{tabular}{|c|c|c|c|c|c|c|}
\hline Questions & Groups & Count & Average & P-value & $\mathbf{F}$ & F crit \\
\hline 1. Sometimes the business also & $\begin{array}{l}\text { private } \\
\text { company }<50\end{array}$ & 55 & 2.945 & \multirow[t]{3}{*}{0.695} & \multirow[t]{3}{*}{0.365} & \multirow[t]{3}{*}{3.072} \\
\hline "suspicious transactions" & $\begin{array}{l}\text { private } \\
\text { company } \geq 50\end{array}$ & 43 & 2.744 & & & \\
\hline do so. & $\begin{array}{l}\text { other } \\
\text { businesses }\end{array}$ & 25 & 3.040 & & & \\
\hline $\begin{array}{l}\text { 4. Temporary distortion a } \\
\text { business's financial }\end{array}$ & $\begin{array}{l}\text { private } \\
\text { company }<50\end{array}$ & 56 & 1.964 & \multirow[t]{3}{*}{0.961} & \multirow[t]{3}{*}{0.039} & \multirow[t]{3}{*}{3.071} \\
\hline & $\begin{array}{l}\text { private } \\
\text { company } \geq 50\end{array}$ & 43 & 2.000 & & & \\
\hline fraud. & $\begin{array}{l}\text { other } \\
\text { businesses }\end{array}$ & 25 & 2.040 & & & \\
\hline $\begin{array}{l}\text { 6. As most micro-entities are } \\
\text { not subjects to audit and review, }\end{array}$ & $\begin{array}{l}\text { private } \\
\text { company }<50\end{array}$ & 55 & 4.545 & \multirow[t]{3}{*}{0.995} & \multirow[t]{3}{*}{0.005} & \multirow[t]{3}{*}{3.072} \\
\hline $\begin{array}{l}\text { more fraud may be found in } \\
\text { their books and financial }\end{array}$ & $\begin{array}{l}\text { private } \\
\text { company } \geq 50\end{array}$ & 42 & 4.524 & & & \\
\hline statements. & $\begin{array}{l}\text { other } \\
\text { enterprises } \\
\text { private }\end{array}$ & 25 & 4.560 & & & \\
\hline $\begin{array}{l}\text { 8. If the head of the business } \\
\text { instructs the accountant to } \\
\text { amend the accounting records }\end{array}$ & $\begin{array}{l}\text { company }<50 \\
\text { employees } \\
\text { private }\end{array}$ & 56 & 2.554 & \multirow[t]{3}{*}{0.380} & \multirow[t]{3}{*}{0.976} & \multirow[t]{3}{*}{3.071} \\
\hline $\begin{array}{l}\text { and / or financial statements, } \\
\text { the accountant will be forced to }\end{array}$ & $\begin{array}{l}\text { company } \geq 50 \\
\text { employees }\end{array}$ & 43 & 2.651 & & & \\
\hline do so. & $\begin{array}{l}\text { other } \\
\text { businesses }\end{array}$ & 25 & 3.120 & & & \\
\hline
\end{tabular}

According to the Table 7, there is no significant difference between attitude to possible fraud of students working in businesses of different types and sizes.

Table 8 summarizes the results of testing the answers to Questions 1, 4, 6 and 8 of the students of Group 1 and Group 3, which in turn were divided into groups, completed by factor of work position as accountants and representatives of other profession. The results show that students working as accountants have shown more indulgent attitude to a possible fraud, committed in the situation of lack of control over fraud. 
Table 8. The results of testing students before taking the course and participants in the professional training programme (broken down by work position)

Questions

Groups

Count Average t Stat

$\mathbf{t}$

\begin{tabular}{|c|c|c|c|c|}
\hline & & & & \\
\hline $\begin{array}{l}\text { 1. Sometimes the business also has to do other } \\
\text { some so-called "suspicious profession } \\
\text { transactions" because competition }\end{array}$ & 74 & 3.014 & 1.077 & 1.660 \\
\hline forces it to do so. & 49 & 2.714 & & \\
\hline $\begin{array}{l}\text { 4. Temporary distortion a business's other } \\
\text { financial performance to obtain an profession }\end{array}$ & 74 & 2.054 & 0.778 & 1.658 \\
\hline accountant & 50 & 1.900 & & \\
\hline $\begin{array}{l}\text { 6. As most micro-entities are not accountant } \\
\text { subjects to audit and review, more fraud }\end{array}$ & 50 & 4.840 & 1.707 & 1.662 \\
\hline $\begin{array}{l}\text { may be found in their books and other } \\
\text { financial statements. }\end{array}$ & 72 & 4.333 & & \\
\hline $\begin{array}{l}\text { 8. If the head of the business instructs accountant } \\
\text { the accountant to amend the accounting }\end{array}$ & 50 & 2.900 & 1.013 & 1.662 \\
\hline $\begin{array}{l}\text { records and / or financial statements, the other } \\
\text { accountant will be forced to do so. profession }\end{array}$ & 74 & 2.568 & & \\
\hline
\end{tabular}

1. Sometimes the business also has to do other transactions" because competition forces it to do so. 


\begin{tabular}{lccccc}
\hline \multicolumn{1}{c}{ Questions } & Groups & Count & Average & t Stat & t Critical one-tail \\
\hline $\begin{array}{l}\text { 6. As most micro-entities } \\
\text { are not subjects to audit }\end{array}$ & $\begin{array}{c}\text { work } \\
\text { experience } \\
\text { w. If the head of the }\end{array}$ & 70 & 4.329 & & \\
$\begin{array}{l}\text { wusiness instructs the } \\
\text { accountant to amend the }\end{array}$ & $\begin{array}{c}\text { experience } \\
<5 \text { years }\end{array}$ & 50 & 3.040 & 1.013 & 1.662 \\
$\begin{array}{l}\text { work } \\
\text { accounting records and / } \\
\text { or financial statements, } \\
\text { the accountant will be }\end{array}$ & $\begin{array}{c}\text { experience } \\
\geq 5 \text { years }\end{array}$ & 72 & 2.500 & & \\
\hline
\end{tabular}

The results show that students with less than 5 years of work experience were more indulgent in their attitude to possible situations of fraud, committed because of presence of fraud triangle's factors of perceived pressure and perceived opportunity.

\section{Discussion}

Summing up the results of the research, the author has proposed some general remarks concerning it:

1. Combining all the questionnaires leads to a remarkable observation: the mean value of the answers given to Questions 1-5 and Question 8 is approximately between 2 and 3 , which means "mostly disagree" to "somewhat disagree" and may be interpreted as rejecting the justification of a possible fraud by a person with an appropriate ethical attitude. Questions 6 and 7 were the only questions about attitude to Fraud Triangle's perceived opportunity factor, testing the attitude to potential fraud, committed in situation of the lack of control over fraud. The mean value of the answers given to all of these questions is between 4 and 5 , which means "neither agree nor disagree" to "somewhat agree". This is a remarkable difference. No matter what target group of students was analysed, the mean value of the answers to these questions differed from the others. There are some possible reasons why these answers differ from the others: (1) with reference to Tennyson (1997), there can be quite a negative prejudice according entrepreneurs, accountants or managers like 'only control prevents people from cheating'; (2) respondents have some experience on this situation or have heard about it.

2. The results of testing of students' answers to 1-8 before and after taking the course "Fraud Examination and Forensic Accounting" show that students before taking the course have more indulgent attitude to possible fraud than the same students after the course towards situations, which are hypothetically widespread with a reasonable excuse. According to RQ1, it can be stated that postgraduate accounting and auditing students' attitudes to fraud before taking the course are somewhat less ethical than after 
completion the course. This is consistent with the conclusions of Nguyen et al. (2008), who found that learning ethics significantly predicts ethical behavioural intention and the more students learn, the less likely they would engage in some scenarios of misbehaviour. Vuckovic-Dekic et al. in 2012 have supposed in their research that the shift in students' attitudes to all kinds of misbehaviour to a more ethical attitude may be the result of detailed explanations by lecturers why scientific fraud is wrong and what damage it causes to science. In this research, the author has supposed the same, that students' attitude towards these situations have changed after lecturer's explanation what these situations really mean and what offenses have been committed.

3. A little bit unexpected results were that students before taking the course have shown more indulgent attitude to fraud compared to students from outside the university. The questions were related to the testing of the attitude to possible fraud, committed in situation of the lack of control over fraud and pressure. These results can be to some extent comparable with results made by Cole \& Smith that "students have weaker ethical values than experienced business people" (Cole \& Smith, 1996: 892). Taking into consideration the fact that there should be no accountants among the students of professional programme, the author supposes that prior to the course, the students had a negative experience of the situations described in the questions at their workplaces. According to the RQ2, the author concludes that postgraduate accounting and auditing students' attitude to fraud is somewhat different from professional programme students' attitude - it is a slightly more indulgent.

4. According to the results of age grouping, the main observation was that the younger the students were, the more indulgent was their attitude to possible fraud committed due to lack of control. One possible reason may be above mentioned reason (1): there can be quite a negative prejudice according entrepreneurs, accountants or managers like 'only control prevents people from cheating'. This result is not exactly consistent with the Callan's 1992 findings that "the gender, age and length of service of the respondent did not substantially influence ethical values" (Callan, 1992: 769).

5. Quite surprising was the result that business-educated students' attitude to possible fraud is more indulgent than attitude of students with other education in a case of fraud, committed in a situation of a poor control. The author assumes that the above-mentioned reasons (1) and (2) are possible explanations of the fact. The same situation is observed when grouping by work position as "accountants" and "other professions". 
6. After grouping the results by students' work experience, the author concluded that students with less than 5 years of work experience are more indulgent in their attitude to possible situations of fraud, committed because of presence of Fraud Triangle's factors of perceived pressure and perceived opportunity. Taking into account the scarcity of work experience, it is supposed that the attitude of students with less work experience is formed mostly on the basis of attitudes of their environment and therefore reason (1) sounds reasonable. Hypothetically, these results correspond to those of Cole \& Smith in 1996: The more the auditor has experience with the company and becomes more familiar he/she is with the corporate culture, the more likely it is that his/her view of typical business ethics may become more positive.

\section{Conclusion}

According to the findings of the research, the course of fraud examination has a slight positive influence on students' perception of fraud situations, connected with company's survival. This fact can be explained by the assumption that during the course the students have learned what kind of offense fraud is, its types and classifications. These results are compatible with results made by Nguyen et al. (2008) and Vuckovic-Dekic et al. (2012).

Contrary to the author's supposition, the results of the research have shown that students without degree in accounting are a little optimistic in their ethical attitude to fraud. The author supposes that the attitude of accounting students' is caused by some negative experience connected with situation of the lack of control in process of financial reporting. If this could be true, it would be a kind of red flag for small businesses that are not subject to audit and review and their internal controllers.

Summarizing the results of the study of student background data, the main conclusion is that younger and less experienced students consider more than others it possible for fraud to be committed in the lack of control over fraud. This conclusion is to some extent in line with Cole \& Smith's (1996) findings. In the author's view this can be caused by students' possible negative prejudice according entrepreneurs, accountants or managers due to their youth and inexperience, which is consistent with Tennyson's (1997) assumptions.

One possible conclusion is that courses on fraud and fraud examination as well as forensic accounting, are essential for accounting professionals and should be an integral part of continuous education of accountants and auditors. The second conclusion is that attitude and therefore judgement and decision-making can be modified by studying professional ethics. In the author's opinion there should be a 
kind of synergy if the course of fraud examination and forensic accounting is combined with course of professional ethics. In the light of the necessity to strengthen ethical judgement of further auditors and accountants, this topic needs to be introduced throughout the course.

\section{References}

Al frijat, Y. S., \& Albawwat, I. E. (2019) „Values, ethics, and attitudes (IES 4) and earnings management from the viewpoint of the financial accountants at Amman Stock Exchange", Accounting and Management Information Systems, vol. 18 no. 3: 379-398

Alrabba, H. M. (2016) „Measuring the impact of code of ethics on the quality of auditors' professional judgement", Journal of Governance and Regulation, vol. 5, no. 4: 54-60

Barrainkua, I., \& Espinosa-Pike, M. (2017) „The influence of auditors' professionalism on ethical judgement: Differences among practitioners and postgraduate students", Revista de Contabilidad-Spanish Accounting Review, vol. 21, no. 2: 176-187

Bierstaker, J. L. (2009) „Differences in attitudes about fraud and corruption across cultures: Theory, examples and recommendations", Cross Cultural Management: An International Journal, vol. 16, no. 3: 241-250

Bruce, R. R. (2012) „Founding an organization theory of work policy as imperative regimes of regulated freedom for ITC development", International Journal of Information Communication Technologies and Human Development, vol. 4, no. 3: 39-55

Callan, V. (1992) „Predicting ethical values and training needs in ethics”, Journal of Business Ethics, vol. 11, no. 11: 761-769

Cole, B. C., \& Smith, D. L. (1996) „Perceptions of business ethics: Students vs. business people", Journal of Business Ethics, vol. 15, no. 8: 889-896

Drogalas, G., Pazarskis, M., Anagnostopoulou, E., \& Papachristou, A. (2017) „The effect of internal audit effectiveness, auditor responsibility and training in fraud detection", Accounting and Management Information Systems, vol. 16, no. 4: 434-454

IAESB (2019) International Education Standard 4, Initial Professional Development - Professional Values, Ethics, and Attitudes (Revised)

Irsyadillah, I., \& Lasyoud, A. A. (2018) „Does accounting education develop ethical maturity? Evidence from Indonesia", Accounting and Management Information Systems, vol. 17, no. 3: 462-483

Jaijairam, P. (2017) „Ethics in accounting”, Journal of Finance and Accountancy, vol. 23: 1-13

Nguyen, N. T., Basuray, M. T., Smith, W. P., Kopka, D., \& McCulloh, D. N. (2008) „Ethics perception: Does teaching make a difference?", Journal of Education for Business, vol. 84, no. 2: 66-75 
Omran, M. S. (2014) „The effect of educating environmental ethics on behavior and attitude to environment protection", European Online Journal of Natural and Social Sciences, vol. 3, no. 3: 141-150

Rennie, S. C., \& Rudland, J. R. (2003) „Differences in medical students' attitudes to academic misconduct and reported behaviour across the years - A questionnaire study", Journal of Medical Ethics, vol. 29, no. 2: 97-102

Reynolds, M. A. (2000) „Professionalism, ethical codes and the internal auditor: A moral argument". Journal of Business Ethics, vol. 24, no. 2: 115-124

Rozidi, M., S., R., A., Nor, N., A., M., Aziz, N., A., Rosli, N., A., Mohaiyadin, N., M., Hj. (2015) „Relationship between auditors' ethical judgments, quality of financial reporting and auditors' attitude towards creative accounting: Malaysia empirical evidence", International Journal of Business, Humanities and Technology, vol. 5, no. 3: 81-87

Samsonova-Taddei, A., \& Siddiqui, J. (2016) „Regulation and the promotion of audit ethics: Analysis of the content of the EU's policy", Journal of Business Ethics, vol. 139, no. 1: 183-195

Singleton, T., King, B., Messina, F. M., \& Turpen, R. A. (2003) „Pro-ethics activities: Do they really reduce fraud?", Journal of Corporate Accounting \& Finance, vol. 14 , no. 6: 85-94

Stum, D. L. (2001) „Maslow revisited: building the employee commitment pyramid", Strategy \& Leadership, vol. 29, no. 4: 4-9

Tennyson, S. (1997) „Economic institutions and individual ethics: A study of consumer attitudes toward insurance fraud", Journal of Economic Behavior \& Organization, vol. 32, no. 2: 247-265

Todorovic, Z. (2018) „Application of the ethics code and rules of professional conduct of accounts and auditors", MEST Journal, vol. 6, vol. no. 2: 135-149

Vassiljev, M., \& Alver, L. (2019) „Behavioral aspects of auditing and the auditor's decision-making as a key cognitive process in the case of fraud", Zeszyty Teoretyczne Rachunkowości, no. 104 (160): 149-169

Vassiljev, M., \& Alver, L. (2016) „Conception and periodisation of fraud models: Theoretical Review", 5th International Conference on Accounting, Auditing, and Taxation, 473-480

Vuckovic-Dekic, L., Gavrilovic, D., Kezic, I., Bogdanovic, G., \& Brkic, S. (2012) "Science ethics education part II: Changes in attitude toward scientific fraud among medical researchers after a short course in science ethics", Journal of B.U.ON., vol. 17 , no. 2: 391-395 


\section{Appendix A. Questionnaire for the first target group before the course}

\begin{tabular}{|c|c|c|c|c|c|c|c|}
\hline \multicolumn{8}{|c|}{ 1. Background issues } \\
\hline 1.1 Gender & \multicolumn{7}{|l|}{ male/female } \\
\hline 1.2 Age & $20-24$ & $25-29$ & $30-34$ & $35-39$ & $40-44$ & $45-49$ & $\begin{array}{c}50- \\
\ldots\end{array}$ \\
\hline $\begin{array}{l}1.3 \\
\text { Education }\end{array}$ & $\begin{array}{c}\text { business } \\
\text { (incl. } \\
\text { accounting) }\end{array}$ & law & technical & $\begin{array}{c}\text { other } \\
\text { (specify) }\end{array}$ & & & \\
\hline $\begin{array}{l}\text { 1.4 Work } \\
\text { position }\end{array}$ & auditor & accountant & $\begin{array}{c}\text { secretary- } \\
\text { managerial } \\
\text { assistant }\end{array}$ & $\mathrm{CFO}$ & $\begin{array}{c}\text { head of the } \\
\text { company }\end{array}$ & $\begin{array}{c}\text { other } \\
\text { (specify) }\end{array}$ & \\
\hline $\begin{array}{l}1.5 \text { Type } \\
\text { and size of } \\
\text { business }\end{array}$ & $\begin{array}{c}\text { private } \\
\text { company } \\
\text { with up to } \\
9 \\
\text { employees }\end{array}$ & \begin{tabular}{|c|} 
private \\
company, \\
$10-49$ \\
employees
\end{tabular} & $\begin{array}{c}\text { a private } \\
\text { company } \\
\text { with over } \\
49 \\
\text { employees }\end{array}$ & \begin{tabular}{|c} 
government \\
agency \\
including \\
local \\
government, \\
foundation, \\
up to 100 \\
employees
\end{tabular} & $\begin{array}{l}\text { government } \\
\text { agency } \\
\text { including } \\
\text { local } \\
\text { government, } \\
\text { foundation, } \\
101-500 \\
\text { employees }\end{array}$ & $\begin{array}{r}\text { govern } \\
\text { agen } \\
\text { includin } \\
\text { govern } \\
\text { founda } \\
\text { with ove } \\
\text { emplo }\end{array}$ & $\begin{array}{l}\text { nent } \\
\text { cy } \\
\text { local } \\
\text { nent, } \\
\text { tion, } \\
\text { r } 500 \\
\text { jees }\end{array}$ \\
\hline
\end{tabular}

2. Questions concerning subject

2.1 Why did you choose the subject "Accounting Fraud and Forensic Accounting Expertise"?

2.2 What are your expectations for the subject?

2.3 Do you consider that the amendment and presentation of any financial statements and / or other documents in a manner that distorts the true value of the organization is a fraud? If not, give an example.

2.4 Please list those financial ratios and accounting records that you believe can be changed later so that they are not fraudulent.

\begin{tabular}{|c|c|c|c|c|c|c|}
\hline $\begin{array}{l}\text { entirely } \\
\text { disagree } \\
\text { (1) }\end{array}$ & $\begin{array}{c}\text { mostly } \\
\text { disagree } \\
(2)\end{array}$ & $\begin{array}{c}\text { somewhat } \\
\text { disagree } \\
\text { (3) }\end{array}$ & $\begin{array}{c}\text { neither agree } \\
\text { nor disagree } \\
(4)\end{array}$ & $\begin{array}{l}\text { somewhat } \\
\text { agree } \\
(5)\end{array}$ & $\begin{array}{l}\text { mostly } \\
\text { agree } \\
\text { (6) }\end{array}$ & $\begin{array}{c}\text { entirely } \\
\text { agree } \\
\text { (7) }\end{array}$ \\
\hline
\end{tabular}

3.1 Sometimes the business also has to do some so-called "suspicious transactions" because competition forces it to do so.

3.2 If an insignificant change in the accounting records and / or financial statements is in the interest of the company, this is permitted.

3.3 The stringent requirements imposed by financial institutions and implementing agencies providing EU grants, force to change the financial reporting to comply.

3.4 Temporary distortion a business's financial performance to obtain an investment or grant is not a fraud.

3.5 When it comes to business "survival", adjustments in accounting and / or financial reporting are justified. 
3.6 As most micro-entities are not subjects to audit and review, more fraud may be found in their books and financial statements.

3.7 Due to inefficiencies in the audit, the accounting records and financial statements may be distorted if necessary.

3.8 If the head of the business instructs the accountant to amend the accounting records and / or financial statements, the accountant will be forced to do so.

3.9 Not everyone can commit fraud. It requires certain traits, such as self-confidence, stress tolerance, disregard for guilt, arrogance.

3.10 The perpetrator (organizer) must be able to lead and attract other people.

3.11 Accounting fraud requires specific competence (accounting, financial management). 3.12 When planning large-scale fraud it is necessary to involve managers and relevant specialists.

\section{Appendix B. Questionnaire for the first target group after the course}

\begin{tabular}{|c|c|c|c|c|c|c|c|}
\hline \multicolumn{8}{|c|}{ 1. Background issues } \\
\hline \multirow{2}{*}{$\begin{array}{l}1.1 \text { Gender } \\
1.2 \text { Age }\end{array}$} & \multicolumn{7}{|l|}{ male/female } \\
\hline & $20-24$ & $25-29$ & $30-34$ & $35-39$ & $40-44$ & $45-49$ & $\begin{array}{c}50- \\
\ldots \\
\end{array}$ \\
\hline $\begin{array}{l}1.3 \\
\text { Education }\end{array}$ & $\begin{array}{l}\text { business } \\
\text { (incl. } \\
\text { accounting) }\end{array}$ & law & technical & $\begin{array}{c}\text { other } \\
\text { (specify) }\end{array}$ & & & \\
\hline $\begin{array}{l}1.4 \text { Work } \\
\text { position }\end{array}$ & auditor & accountant & $\begin{array}{c}\text { secretary- } \\
\text { managerial } \\
\text { assistant }\end{array}$ & $\mathrm{CFO}$ & $\begin{array}{c}\text { head of the } \\
\text { company }\end{array}$ & $\begin{array}{c}\text { other } \\
\text { (specify) }\end{array}$ & \\
\hline $\begin{array}{l}1.5 \text { Type } \\
\text { and size of } \\
\text { business }\end{array}$ & $\begin{array}{c}\text { private } \\
\text { company } \\
\text { with up to } \\
9 \\
\text { employees }\end{array}$ & $\begin{array}{c}\text { private } \\
\text { company, } \\
10-49 \\
\text { employees }\end{array}$ & $\begin{array}{c}\text { a private } \\
\text { company } \\
\text { with over } \\
49 \\
\text { employees }\end{array}$ & $\begin{array}{c}\text { government } \\
\text { agency } \\
\text { including } \\
\text { local } \\
\text { government, } \\
\text { foundation, } \\
\text { up to } 100 \\
\text { employees }\end{array}$ & $\begin{array}{l}\text { government } \\
\text { agency } \\
\text { including } \\
\text { local } \\
\text { government, } \\
\text { foundation, } \\
101-500 \\
\text { employees }\end{array}$ & $\begin{array}{r}\text { govern } \\
\text { agen } \\
\text { includin } \\
\text { govern } \\
\text { founda } \\
\text { with ove } \\
\text { emplo }\end{array}$ & $\begin{array}{l}\text { ment } \\
\text { cy } \\
\text { local } \\
\text { nent, } \\
\text { tion, } \\
\text { r } 500 \\
\text { yees }\end{array}$ \\
\hline
\end{tabular}

2.1 Did you receive any answers to your questions during the course? Has your attitude toward/understanding of accounting fraud changed?

2.2 What do you think are the most interesting / necessary topics in the course "Accounting Fraud and Forensic Accounting Expertise"? Can / should any certain topics be changed?

2.3 How do you evaluate the materials used in the subject, including compulsory literature? Whether all materials were relevant and comprehensible?

2.4 If you would like to add more about the subject you give feedback on, please do it here. 


\begin{tabular}{|c|c|c|c|c|c|c|}
\hline \multicolumn{7}{|c|}{ 3. Likert scale questions } \\
\hline $\begin{array}{l}\text { entirely } \\
\text { disagree } \\
\text { (1) }\end{array}$ & $\begin{array}{c}\text { mostly } \\
\text { disagree } \\
\text { (2) }\end{array}$ & $\begin{array}{c}\text { somewhat } \\
\text { disagree } \\
\text { (3) }\end{array}$ & $\begin{array}{c}\text { neither } \\
\text { agree nor } \\
\text { disagree (4) }\end{array}$ & $\begin{array}{l}\text { somewhat } \\
\text { agree } \\
(5)\end{array}$ & $\begin{array}{c}\text { mostly } \\
\text { agree (6) }\end{array}$ & $\begin{array}{l}\text { entirely } \\
\text { agree (7) }\end{array}$ \\
\hline
\end{tabular}

3.1 Sometimes the business also has to do some so-called "suspicious transactions" because competition forces it to do so.

3.2 If an insignificant change in the accounting records and / or financial statements is in the interest of the company, this is permitted.

3.3 The stringent requirements imposed by financial institutions and implementing agencies providing EU grants, force to change the financial reporting to comply.

3.4 Temporary distortion a business's financial performance to obtain an investment or grant is not a fraud.

3.5 When it comes to business "survival", adjustments in accounting and / or financial reporting are justified.

3.6 As most micro-entities are not subjects to audit and review, more fraud may be found in their books and financial statements.

3.7 Due to inefficiencies in the audit, the accounting records and financial statements may be distorted if necessary.

3.8 If the head of the business instructs the accountant to amend the accounting records and / or financial statements, the accountant will be forced to do so.

3.9 Not everyone can commit fraud. It requires certain traits, such as self-confidence, stress tolerance, disregard for guilt, arrogance.

3.10 The perpetrator (organizer) must be able to lead and attract other people.

3.11 Accounting fraud requires specific competence (accounting, financial management). 3.12 When planning large-scale fraud it is necessary to involve managers and relevant specialists.

\section{Appendix C. Questionnaire for the second target group}

\begin{tabular}{|c|c|c|c|c|c|c|c|}
\hline \multicolumn{8}{|c|}{ 1. Background issues } \\
\hline \multirow{2}{*}{$\begin{array}{l}1.1 \text { Gender } \\
1.2 \text { Age } \\
\end{array}$} & \multicolumn{7}{|l|}{ male/female } \\
\hline & $20-24$ & $25-29$ & $30-34$ & $35-39$ & $40-44$ & $45-49$ & $50-\ldots$ \\
\hline 1.3 Education & $\begin{array}{c}\text { business (incl. } \\
\text { accounting) }\end{array}$ & law & technical & $\begin{array}{c}\text { other } \\
\text { (specify) }\end{array}$ & & & \\
\hline $\begin{array}{l}\text { 1.4 Work } \\
\text { position }\end{array}$ & auditor & accountant & $\begin{array}{c}\text { secretary- } \\
\text { managerial } \\
\text { assistant }\end{array}$ & $\mathrm{CFO}$ & $\begin{array}{c}\text { head of the } \\
\text { company }\end{array}$ & $\begin{array}{c}\text { other } \\
\text { (specify) }\end{array}$ & \\
\hline
\end{tabular}


The impact of fraud-themed course on students' attitude to fraud. Does previous studies and background matter?

\begin{tabular}{|c|c|c|c|c|c|c|}
\hline $\begin{array}{l}1.5 \text { Type and } \\
\text { size of } \\
\text { business }\end{array}$ & $\begin{array}{c}\text { private } \\
\text { company with } \\
\text { up to } 9 \\
\text { employees }\end{array}$ & $\begin{array}{c}\text { private } \\
\text { company, } \\
10-49 \\
\text { employees }\end{array}$ & $\begin{array}{c}\text { a private } \\
\text { company with } \\
\text { over } 49 \\
\text { employees }\end{array}$ & $\begin{array}{c}\text { government } \\
\text { agency } \\
\text { including } \\
\text { local } \\
\text { government, } \\
\text { foundation, } \\
\text { up to } 100 \\
\text { employees }\end{array}$ & $\begin{array}{l}\text { government } \\
\text { agency } \\
\text { including } \\
\text { local } \\
\text { government, } \\
\text { foundation, } \\
101-500 \\
\text { employees }\end{array}$ & $\begin{array}{l}\text { government agency } \\
\text { including local } \\
\text { government, } \\
\text { foundation, with over } \\
500 \text { employees }\end{array}$ \\
\hline
\end{tabular}

2. Questions concerning subject

2.1 Do you consider that the amendment and presentation of any financial statements and / or other documents in a manner that distorts the true value of the organization is a fraud? If not, give an example.

2.2 Please list those financial ratios and accounting records that you believe can be changed later so that they are not fraudulent.

3. Likert scale questions

\begin{tabular}{c|c|c|c|c|c|c}
$\begin{array}{c}\text { entirely } \\
\text { disagree } \\
(1)\end{array}$ & $\begin{array}{c}\text { mostly } \\
\text { disagree } \\
(2)\end{array}$ & $\begin{array}{c}\text { somewhat } \\
\text { disagree } \\
(3)\end{array}$ & $\begin{array}{c}\text { neither agree nor } \\
\text { disagree (4) }\end{array}$ & $\begin{array}{c}\text { somewhat } \\
\text { agree } \\
(5)\end{array}$ & $\begin{array}{c}\text { mostly agree } \\
\text { agree }\end{array}$ & $\begin{array}{c}\text { entirely } \\
\text { agree }\end{array}$ \\
\hline
\end{tabular}

3.1 Sometimes the business also has to do some so-called "suspicious transactions" because competition forces it to do so.

3.2 If an insignificant change in the accounting records and / or financial statements is in the interest of the company, this is permitted.

3.3 The stringent requirements imposed by financial institutions and implementing agencies providing EU grants, force to change the financial reporting to comply.

3.4 Temporary distortion a business's financial performance to obtain an investment or grant is not a fraud. 3.5 When it comes to business "survival", adjustments in accounting and / or financial reporting are justified.

3.6 As most micro-entities are not subjects to audit and review, more fraud may be found in their books and financial statements.

3.7 Due to inefficiencies in the audit, the accounting records and financial statements may be distorted if necessary.

3.8 If the head of the business instructs the accountant to amend the accounting records and / or financial statements, the accountant will be forced to do so.

3.9 Not everyone can commit fraud. It requires certain traits, such as self-confidence, stress tolerance, disregard for guilt, arrogance.

3.10 The perpetrator (organizer) must be able to lead and attract other people.

3.11 Accounting fraud requires specific competence (accounting, financial management).

3.12 When planning large-scale fraud it is necessary to involve managers and relevant specialists.

i Replaced by the course "Fraud Examination and Ethics" from the academic year 2019/2020.

ii Students before taking the course "Fraud Examination and Forensic Accounting".

iii Students after completing the course "Fraud Examination and Forensic Accounting".

iv Participants in the professional training programme "Accountant-financial officer". 